\title{
The Effect of Coronavirus Pandemic and Recognition on Bitcoin with Precious Metal Prices: A Causality Analysis ${ }^{1}$
}

\author{
Ahmet ŞERBETÇi \\ Assit. Prof, Kahramanmaraş Sütçü İmam University \\ Vocational School of Social Sciences, Administration and Organization \\ Department \\ ahmetserbetci@ksu.edu.tr \\ Orcid ID: https://orcid.org/0000-0002-6828-5319 \\ Yaşar ALPTÜRK \\ University Lecturer, Kahramanmaraş Sütçü İmam University \\ Vocational School of Social Sciences, Accounting and Tax Department \\ yasaralpturk@ksu.edu.tr \\ Orcid ID: https://orcid.org/0000-0003-0063-4479 \\ Turgay CEYHAN \\ Assit. Prof, Burdur Mehmet Akif Ersoy University \\ Bucak Business Administration Faculty, Economics and Finance Department \\ tceyhan@mehmetakif.edu.tr \\ Orcid ID: https://orcid.org/0000-0001-5225-297X
}

\begin{abstract}
Coronavirus (COVID-19), which emerged as an epidemic in China in December 2019, has been recognized as a pandemic by the World Health Organization as of March 2020. Events regarding the coronavirus shocked the markets and were seen as a threat to the markets. In this context, this study aims to examine the effect of the COVID-19 on Bitcoin prices and precious metals which are seen as low-risk assets in global markets.

In the study, the causality relationship between the daily number of COVID19 cases approved by the WHO and Google trends, and the price series of Bitcoin, Gold, Silver, Platinum, Palladium was investigated to determine the effects of the developments in the course of the epidemic on the prices of Bitcoin and precious

\footnotetext{
${ }^{1}$ Makale Geliş/Kabul Tarihi: 22.05.2021 / 12.11.2021

Künye Bilgisi: Şerbetçi, A., Alptürk, Y. ve Ceyhan, T. (2021). Koronavirüs salgına ve bilinirliğinin bitcoin ile kıymetli metal fiyatları üzerindeki etkisi: Bir nedensellik analizi. Kahramanmaraş Sütçü İmam Üniversitesi Sosyal Bilimler Dergisi, 18 (3), 2229-2250. DOI: $10.33437 /$ ksusbd.941153
} 
metals. Toda-Yamamoto causality test was performed in the study where daily data were used between 19.01.2020-31.03.2021.

According to the findings, a causality relationship could not be determined between the number of COVID-19 cases with Bitcoin and precious metals while it was observed that the recognition of COVID-19 has a very strong causal effect on Bitcoin prices and the prices of other precious metals except silver. In addition, a reciprocal causality relationship has been identified between the confirmed COVID-19 cases and the recognition of COVID-19.

Keywords: COVID-19, Bitcoin, Precious Metals.

\section{Koronavirüs Salgını ve Bilinirliğinin Bitcoin ile Kıymetli Metal Fiyatları Üzerindeki Etkisi: Bir Nedensellik Analizi}

Öz

Çin'de Aralık 2019`da bir salgın hastalık olarak ortaya çıkan Koronavirüs (COVID-19) Mart 2020 tarihi itibariyle Dünya Sağlık Örgütü (DSÖ) tarafından bir pandemi olarak kabul edilmiştir. Koronavirüsle ilgili yaşanan gelişmeler piyasalar için şok etkisi yaratmış ve piyasalar için bir tehdit olarak görülmüştür. Bu kapsamda bu çalışmada, salgının küresel piyasalarda düşük riskli varlık olarak görülen değerli metaller ve Bitcoin fiyatları üzerindeki etkisinin incelenmesi amaçlanmıştır.

Çalışmada salgının seyrindeki gelişmelerin Bitcoin ve değerli metallerin fiyatlarına etkilerini tespit etmek amacıyla DSÖ tarafından onaylanmış günlük COVID-19 vaka sayıları ve Google trends verileri ile Bitcoin, Altın, Gümüş, Platinyum, Paladyum fiyat serileri arasındaki nedensellik ilişkisi araştırılmıştır. 19.01.2020 - 31.03.2021 tarihleri arası günlük verilerinin kullanıldığı çalışmada Toda-Yamamoto nedensellik testi gerçekleştirilmiştir.

Çalışmanın bulgularına göre; COVID-19 vaka sayıları ile Bitcoin ve değerli metaller arasında bir nedensellik ilişkisi tespit edilemezken, COVID-19 bilinirliğinin gümüş dışındaki kıymetli metallerin fiyatları ile Bitcoin fiyatlarını güçlü bir biçimde etkilediği gözlenmiştir. Ayrıca COVID-19 onaylanmış vakalar ile COVID-19 bilinirliği arasında karşılıklı bir nedensellik ilişkisi tespit edilmiştir.

Anahtar Kelimeler: COVID-19, Bitcoin, Kiymetli Metaller. 
A.Serbetci-Y.Alptürk-T.Ceyhan $\quad$ Koronavirüs Salgını ve Bilinirliği...

\section{INTRODUCTION}

Investors take decisions on risk and return axis while investing in assets or securities in global markets. Due to this main rule of thumb, estimating risk and return becomes one of the primary functions of the field of economics and finance. The necessity to estimate risk has induced researchers to develop methods based on statistics. Unfortunately, taking decisions by using these methods does not always yield exact results. Global shocks caused by unexpected events like suddenly occurred events and macro effective developments turn these accounts upside down. One of the most notable and tragic examples is that the coronavirus (COVID-19) pandemic that emerged in mid-December 2019.

When the dates showed 31 December 2019, the WHO Office in China reported cases of pneumonia of unidentified etiology in Wuhan, China's Hubei province. On January 07, 2020, the causal agent was identified as a new type of coronavirus (2019-nCoV) that has never been seen in humans before. The 2019$\mathrm{nCoV}$ disease was later recognized as COVID-19, and the virus was named SARS-CoV-2 because of its similarity with SARS-CoV (Ministry of Health, 2020: 5).

The WHO declared the COVID-19 outbreak as an internationally concerned public health emergency on 30 January 2020. While efforts are being made all over the world to the spread of the new strain and being worked on its treatment and prevention, it has been seen that COVID-19 causes not only human deaths but also destroys the social and economic order in the world. The impact of pandemics is beyond imagination and not limited to lives lost, and can endanger the economic stabilization and existence of the influenced countries (Bobdey and Ray, 2020: 9).

Aiming to investigate the effect of COVID-19 on several assets prices, this study is structured as five sections. Following a brief introduction, the second section covers the review of the literature conducted on relations between epidemics, Bitcoin and precious metals. In the third section, the data set and research method used in the study are introduced. In the fourth section, findings gathered from the causality analysis are presented. Finally, in the fifth section titled as conclusion, the findings of the study are discussed and recommendations are made for future studies and related parties.

\section{LITERATURE REVIEW}

While conducting a literature review for this study, it is determined some studies in which interested to financial effects of the epidemic diseases that occurred previously such as SARS, Ebola, Dengue. In addition, literature summary including Bitcoin and precious metals has been investigated. While 
designing the literature studies examined, classified in two sections related topics as the literature on Disease and Pandemic and literature on Bitcoin and Precious Metals.

\section{The Literature on Disease and Outbreaks}

While preparing literature reviews about coronavirus or other outbreaks, preferred its causes and effects relationship rather than a certain range. Because the studies conducted in general have been made by considering the period of disease or spread of outbreaks. Accordingly, the literature summaries, which are already limited, are designed and presented according to chronological order. Loh (2006) examined the impact of the SARS pandemic on airline stocks in Canada, China, Thailand, Hong Kong and Singapore. Author found that the SARS negatively affected the returns of airline stocks and that the SARS does not have a significant impact on the volatility of market returns, excepting Singapore where volatility was considerably increased. Chen et al. (2007) investigated the effect of the SARS outbreak on Taiwanese hotel stock prices and determined that the epidemic negatively affected its stock performance. Armien et al. (2008) calculated the costs of controlling the Dengue epidemic in Panama and found that there were significant decreases in hotel stock prices during the outbreak. Giudice and Paltrinieri (2017) investigated the effect of Ebola virus on capital flows on 78 mutual fund samples in African countries over the period 2006-2015. The results showed that Ebola outbreak had a negative effect on capital flows. Zeren and Hizarc1 (2020) aim to find out the probable influences of COVID-19 on share markets. The probable influences on stock exchanges are investigated using Maki (2012) cointegration test using both COVID-19 total death and COVID-19 total case. According to the empirical findings, all exchanges examined with total death act together in the long-term. It is understood that total cases have cointegration link with SSE, KOSPI and IBEX35 and there is no cointegration link with FTSE MIB, CAC40, DAX30. Öztürk et al. (2020) try to explain the effects of the COVID-19 outbreak on the financial sector by examining daily data using the fixed-effect model. The findings show that financial markets are highly affected by the number of cases in Turkey. Besides, it is concluded that while the banking and insurance sectors were adversely affected by the COVID-19 epidemic, the real estate investment sectors were least affected by the epidemic. Temür (2021) concludes that the COVID-19 outbreak leads to sharp decreases in the stock exchange and the prices of stocks in the BIST-retail industry.

\section{The Literature on Bitcoin and Precious Metals}

Batten et al. (2010) analyze the fluctuation in precious metals and whether various macroeconomic variables affect this fluctuation with monthly data for the period of January 1986-May 2006. According to the results of the analysis, the 
volatility of silver cannot be explained by monetary variables, but it is determined that the same situation is not the case for gold.

Arouri et al. (2012) discuss the long-term relationship in precious metal prices based on the period of January 1999-March 2011. Palladium, platinum, gold and silver are used in analysis as a precious metal. According to the findings, a longterm relationship is found between the returns and fluctuations of precious metals.

Aksoy and Topçu (2013) analyze the relationships between gold and the variables by using the data of producer price index, consumer price index, government debt securities and stocks between January 2003 and December 2011 with Engle-Granger Cointegration Test, Granger Causality Test and Johansen Cointegration Test. According to the results of the mentioned study, Cointegration Analysis indicates that series are integrated and there exist a longterm relationship between these variables.

Reboredo (2013) discusses whether there is a long-term relationship between commodities and whether commodities are alternative to oil. In this context, the period of January 2000-September 2011 is taken as monthly basis. According to the results of the analysis, it has been determined that there is a positive relationship between commodities and gold can be a safe port in investment instruments against price volatility in oil.

Karataş and Ürkmez (2013) analyze some critical macroeconomic indicators that determine the gold price in the 2007M01-2013M02 crisis period. In the study, Index of Dow Jones, oil and silver prices are discussed as factors determining gold prices in the global financial crisis. Within the framework of the findings obtained, it is commented that the price of gold increased during the crisis periods and is affected in the long-term as expected.

Lucey and Li (2015) want to determine whether precious metals (palladium, platinum, silver and gold) are seen as a safe port (less risky assets) for investors. In this context, the authors compare the S\&P500 and 10-year government bonds index with precious metals. In this context, according to the results of the analysis covering the years 1989-2013, they state that investors regard silver, platinum and palladium as safe ports, but the same situation is not the effectual for gold.

Dyhrberg (2016) runs GARCH models to test how Bitcoin prices act as financial assets such as gold and dollar prices between 19.07.2010 and 22.05.2015. Looking at the results of the study, they find that the responses of Bitcoin prices react in the same direction as those of the dollar and gold prices.

Bouri et al. (2017a) explain the daily price returns of Bitcoin using a data set expressing various currencies. Authors, who examine the condition before and 
after the crisis in 2013, find that there is a statistically significant and negative relationship between past shocks and the fluctuation before the crisis, and there is no significant relationship between past shocks and the fluctuation after the crisis. It is also found that there is a negative relationship between the implicit volatility index VIX and Bitcoin.

Bouri et al. (2017b) test whether Bitcoin is a hedging tool against global uncertainties over the period March 17, 2011-October 7, 2016. Quantile regressions reveal that Bitcoin has a protective role against uncertainty, that is, Bitcoin returns react positively to uncertainty at both higher quantiles and briefer frequency movements. Lastly, hedging is beholded at briefer investment horizons, and at both lower and upper ends when quantile-on-quantile regressions are used. Findings are that Bitcoin is a sheltered haven in the uncertainty.

Bouri et al. (2017c) examine whether Bitcoin is a reliable protection tool or not with energy commodity index and general commodity index. The DCCGARCH model is used in the study conducted for the 2010 July-2015 December period. Analysis results show that Bitcoin is a safe port for the energy sector, but not safe for nonenergy products.

In another study conducted by Bouri et al. (2017d), it has been investigated whether Bitcoin can be a safe port for major world stock indices, bonds, oil, gold, general commodity index and US dollar index. In the study in which daily and weekly data for the period of July 2011-December 2015 are used and the Dynamic Conditional Correlation model is applied, it is concluded that Bitcoin is a weak hedge and is only suitable for diversification purposes. It has been explained that Bitcoin is only safe against Asian stocks.

Balcilar et al. (2017) investigate the causality relationship between Bitcoin trading volume and its return volatility by employing the Quantiles Approach with daily data from December 19, 2011 to April 25, 2016. Results reveal that while trading volume is determinant in predicting Bitcoin returns, it is not determining volatility.

Blau (2017), in its study of price dynamics and speculative trading in Bitcoin with GARCH model through 2010-2014 data, observes that the speculative trading doesn't have a significant effect on increasing or decreasing Bitcoin prices.

Cermak (2017) uses a GARCH $(1,1)$ model to analyze Bitcoin's price changes with respect to the macroeconomic variables of the countries where Bitcoin is most traded. Author argues that Bitcoin is not a safe port due to its price volatility, except China. 


\section{$\underline{\text { A.Serbetci-Y.Alptürk-T.Ceyhan } \quad \text { Koronavirüs Salgını ve Bilinirliğgi... }}$}

Bhatia et al. (2018) discuss the relationship between gold, silver, platinum and palladium prices with causality analysis. In this context, the authors examine the period of April 2000-June 2016. According to the results of the empirical analysis, it is reached that there is a causality relationship between precious metals during the periods of low price volatility, while there is no causal relationship between precious metal prices during the rise and fall periods.

Bouri et al. (2018) investigate the effect of gold and commodity index prices on Bitcoin prices with nonlinear ARDL model by daily data of July 17, 2010February 2, 2017. It is determined that there is a nonlinear, asymmetric quantile relationship between the commodity index-bitcoin and gold-bitcoin.

Peng et al. (2018) predict the volatility of cryptocurrencies whose names are Bitcoin, Ethereum and Dash by daily and hourly frequency data within the framework of various GARCH models. Results produced by the SVR-GARCH model for three variables examined are found to be statistically more significant than other models.

Tiwari et al. (2018), in the study where they examine the Bitcoin efficiency using daily prices for the period 2010-2017 with different empirical methods, determine the Bitcoin market to be efficient except for the period April-August 2013 and August-November 2016.

Y1ldirım (2018) questions the existence of a statistically significant relationship between Bitcoin prices and gold prices in the short-term and longterm with the Corrected Least Squares Model and Johansen Cointegration Test. In the study, in which daily price data is used periodically between February 2, 2012 and December 31, 2013, 490 daily data are studied. As a result of the analysis, a significant relationship is found between the variables in the shortterm. Moreover, it is observed that gold price movements affect Bitcoin prices in the long-term while the Bitcoin price movements do not affect gold prices.

Çelik et al. (2019) investigate the presence of price bubble in palladium, platinum, silver and gold and prices from precious metals between 01.01.201019.02.2019. SADF, GSADF and RtADF methods are used in research. According to the analysis, it is concluded that there is a price bubble in gold, silver and platinum prices and no price bubble in palladium price. In the study, the volatility spread between gold, platinum and silver returns is investigated by using the VAR-EGARCH method. As a result of the analysis, it is concluded that multiple spillovers between the returns of these precious metals and also determined that the price bubble affect each other.

Açacak et al. (2020) analyze the relationships between gold, platinum, rhodium, ruthenium, silver, osmium, palladium, iridium, and rhenium which are 
precious metals using weekly data between 08.09.2009-12.02.2019. In the study conducted using Granger and Asymmetric Causality Models, they find the causality between precious metals.

Avşarlıgil (2020) examines the relationship of the Covid-19 outbreak with Bitcoin (BTC), West Texas Crude Oil Price (WTI) and Euro prices using BTC/USD, EUR/USD and WTI daily prices between 03.04.2020-11.01.2018. Cointegration Analysis conducted for the pre-epidemic period shows that the variables of West Texas Crude Oil Price, Bitcoin and Euro / Dollar parity are not cointegrated with each other, and these three variables act co-integrated in the post-epidemic period. The results of the Granger Causality analysis show that there is a causality from Bitcoin to West Texas Crude Oil Prices and from West Texas Crude Oil Prices to Euro in the pre-epidemic period. However, it has been determined that there is a causality from West Texas Crude Oil Prices to Bitcoin prices in the post-epidemic period. In addition, it is seen that Euro prices are a granger cause of West Texas Crude Oil Prices after the epidemic while West Texas Crude Oil Prices are a granger cause of Euro prices before the epidemic.

Gülcan (2021) measures the response of precious metals and energy products to the COVID-19 pandemic by using the Toda-Yamamoto and Hatemi-J asymmetric causality test for Turkey. Toda-Yamamoto causality test results show that there is a causality relationship from daily death to palladium. According to the results of Hatemi-J asymmetric causality test, there is an asymmetric causality relationship from death negative shocks to silver negative shocks, from patient positive shocks to palladium positive shocks, and recovering positive shocks to crude oil positive shocks.

Iqbal et al. (2021) investigate the effect of the COVID-19 pandemic's changing intensity on cryptocurrency market returns. In the study, the quantileon-quantile regression model is used and concluded that the changing intensity levels of the pandemic asymmetrically affect bear and bull market scenarios of cryptocurrencies. In addition, it is noted that what responses cryptocurrencies give to the changes in the intensity of the pandemic differ.

\section{METHODOLOGY}

\section{Aim of the Study and Data}

The aim of this study is to investigate the effect of the coronavirus on the prices of Bitcoin and selected precious metals. In this context, confirmed COVID-19 cases and Google Trends data are used to measure the COVID-19. Gold, silver, platinum and palladium are chosen for precious metals. TodaYamamoto Causality Test is conducted in the study where the daily data is used 


\section{A.Serbetci-Y.Alptürk-T.Ceyhan $\quad$ Koronavirüs Salgını ve Bilinirliğgi...}

between 19.01.2020 and 31.03.2021. In addition, COVID-19 data is provided through Google Trends and WHO while other variables are obtained from investing.com on daily frequency. In the analysis, the natural logarithm of the variables is taken, and the data between 19.01.2020 and 31.03.2021 are used. The reason we choose these dates is that it reflects the pandemic process and is up to date.

Table 1. Data Set

\begin{tabular}{|c|c|c|c|c|c|}
\hline Variables & $\begin{array}{r}\text { Va } \\
\text { Des }\end{array}$ & $\begin{array}{l}\text { ble } \\
\text { tion }\end{array}$ & Source & $\begin{array}{c}\text { Time } \\
\text { Period }\end{array}$ & $\begin{array}{c}\text { Period of } \\
\text { Data }\end{array}$ \\
\hline COVID & Confirmed & e Numbers & covid19.who.int & 19 & \multirow{7}{*}{ Daily } \\
\hline TRENDS & \multicolumn{2}{|c|}{ Google Search Frequency } & trends.google.com & January & \\
\hline BTC & Bitcoin & \multirow{5}{*}{$\begin{array}{l}\text { Closing } \\
\text { Prices }\end{array}$} & \multirow{5}{*}{ investing.com } & 2020 & \\
\hline GOLD & Gold & & & 31 & \\
\hline SLVR & Silver & & & $\begin{array}{c}31 \\
\text { March }\end{array}$ & \\
\hline PLAT & Platinum & & & 2021 & \\
\hline PALAD & Palladium & & & & \\
\hline
\end{tabular}
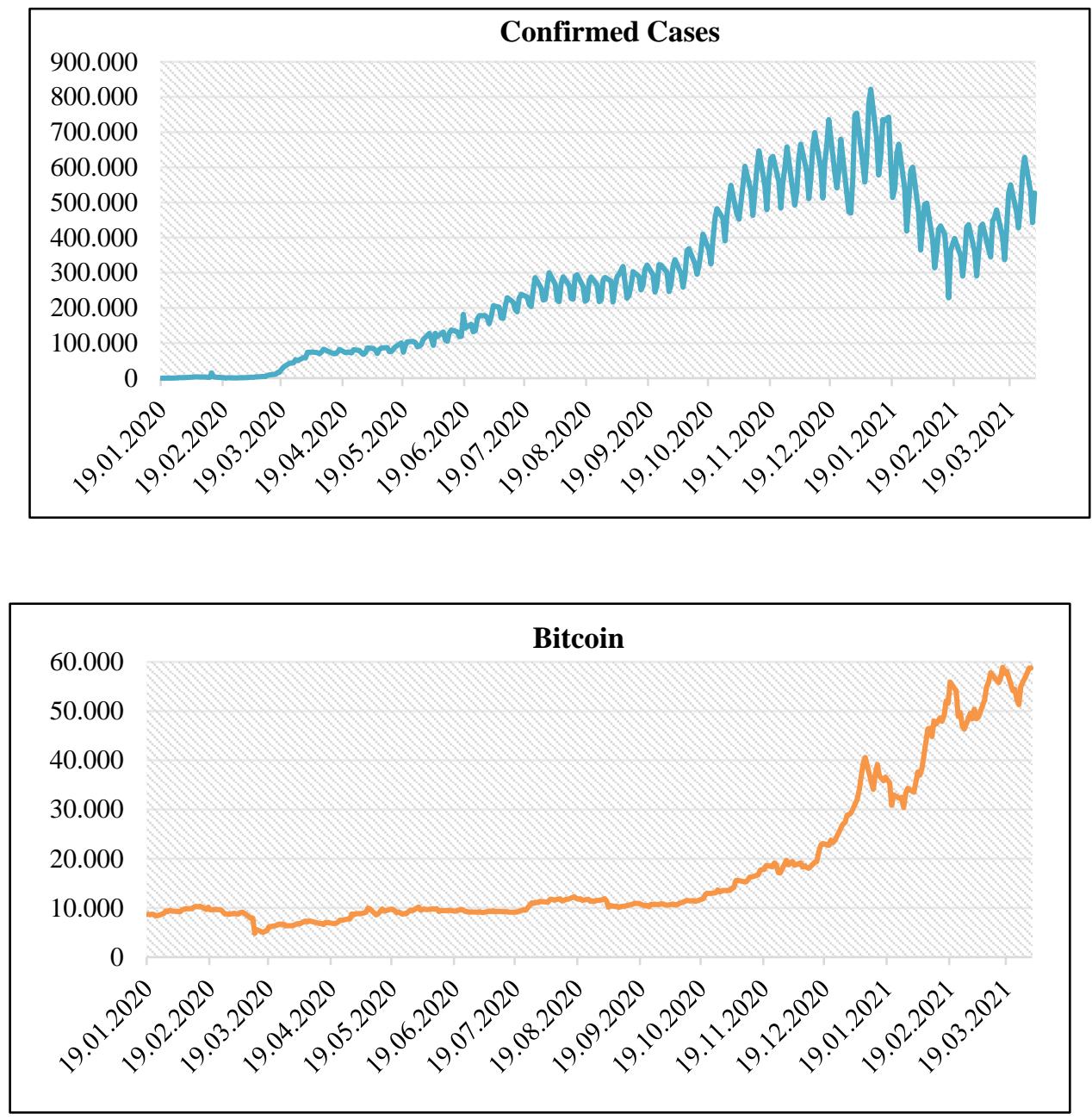

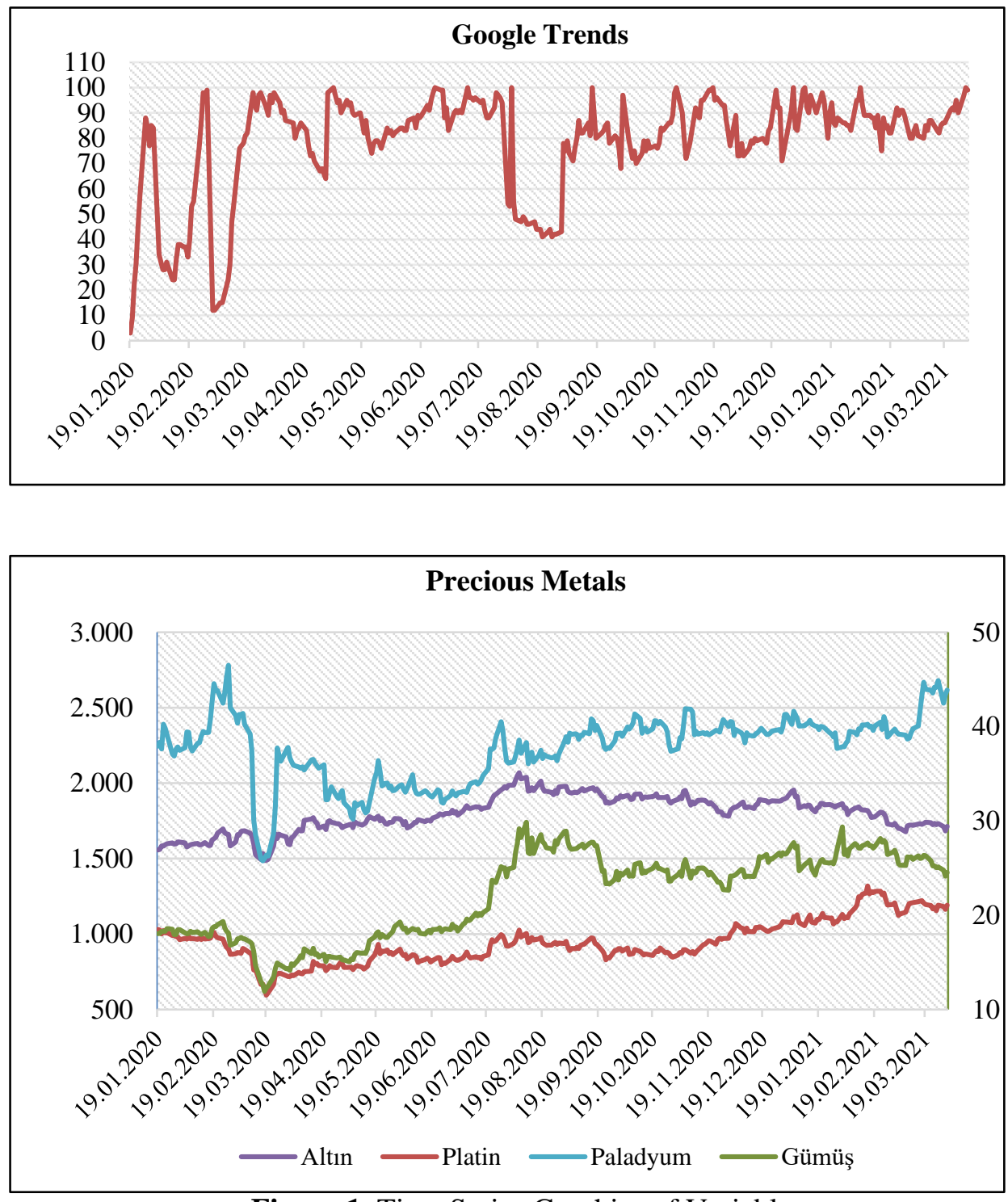

Figure 1. Time Series Graphics of Variables 


\section{$\underline{\text { A.Serbetci-Y.Alptürk-T.Ceyhan } \quad \text { Koronavirüs Salgını ve Bilinirliğgi... }}$}

\section{Hypotheses and Analysis Method}

Time series analyzes are used to examine the relationship between coronavirus (COVID-19) and Bitcoin, precious metals. In time series analysis, stationarity is important in order to analyze other movements of variables and to generalize them to other periods. It is not possible to examine other movements of a non-stationary variable. However, other movements of the variable can be examined for the stationary variables. In addition, if there is more than one nonstationary time series, the regression analysis with these time series will be false or meaningless (Gujarati, 2016: 320).

Lee-Strazicich (2003) unit root test is used to investigate the relationship between these variables, which also takes into account the structural breaks and tests the stability. After the series have been recovered from the root of the unit, the optimal lag length is determined according to the Akaike Information Criterion (AIC). Toda-Yamamoto (1995) analysis is applied in the form of dual analysis in order to determine whether there is any causality between the series and if causality is present.

In the research, many hypotheses will be tested in relation to whether the data sets have structural breaks or not, whether they contain unit roots, whether the data sets are trending, and whether there is a relationship between the data. However, the basic $\left(H_{0}\right)$ and alternative $\left(H_{1}\right)$ hypothesis of the research is as follows;

$\boldsymbol{H}_{\mathbf{0}}$ : There is no causality relationship between the variables of the number of COVID-19 cases and the recognition of COVID-19 and the Bitcoin, Gold, Silver, Platinum, Palladium variables.

$H_{1}$ : There is a causality relationship between the variables of the number of COVID-19 cases and the recognition of COVID-19 and the Bitcoin, Gold, Silver, Platinum, Palladium variables.

\section{Lee-Strazicich Unit Root Test}

To investigate the relationship between the variables, the stationarity of variables (whether they are unit root or not) should be tested first. ADF, PP, etc. unit root tests are some of the stationary tests. However, these tests do not take into account structural breaks. For this reason, Lee-Strazicich (2003) unit root test which takes into account the structural breaks and tests the stability is applied to the data.

Unlike conventional ADF based structural break unit root tests, the LM unit root test also allows breaks under the null hypothesis. Accordingly, the LM unit 
root test has several advantages. Since the breakpoints are initially determined as endogenous, the test is not subject to false refusals in case of breaks and the presence of the unit root. The most important thing is that if the alternative hypothesis is correct, there are no false rejections. The rejection of the zero hypothesis in the LM test does not necessarily imply the rejection of the unit root, but the rejection of the unit root without breaks. (Özcan, 2012: 10; Lee and Strazicich, 2004: 2; Lee and Chang, 2008: 316).

As a correction to these criticisms by Lee-Strazicich (2003, 2004), a new unit root test has been added to the literature. According to this new test, structural breakage can be allowed in each of the basic and alternative hypotheses. The method used in the LM unit root test is as follows;

$$
y_{1}=\delta Z_{t}+e_{t} \quad e_{t}=\beta e_{t-1}+\varepsilon_{t}
$$

In equation (1), the " $Z_{t}$ " external variables vector denotes error terms with the property $\varepsilon_{t} \sim$ iid $N\left(0, \sigma^{2}\right)$. The model that includes two changes in the level is expressed as A $Z_{t}=\left[1, t, D_{1 t}, D_{2 t}\right]$. Here; for $D_{j t}=1, t \geq T_{b j}+1, j=$ 1,2 and 0 for other cases. $T_{b j}$ shows the break time. Model $C$ contains 2 changes in trend and level, model $Z_{t}=\left[1, t, D_{1 t}, D_{2 t}, D T_{1 t}, D T_{2 t}\right]$. Here; $D T_{j t}=t-$ $T_{b j}$ for $t \geq T_{b j}+1, j=1,2$ and 0 for other cases. While the process of data creation (DGP) includes breaks under the basic hypothesis $(\beta=1)$, it is in the form of an alternative hypothesis $(\beta<1)$. Lee and Strazicich use the following equation to obtain the LM unit root test statistics.

$$
\Delta y_{t}=\delta^{\prime} \Delta Z_{t}+\varnothing \tilde{S}_{t-1}+u
$$

Here; $\tilde{S}_{t}=y_{t}-\tilde{\psi}_{x}-Z \delta, t=2, \ldots . T$; and $\tilde{\delta}$ value is the coefficient obtained from $\Delta Z_{t}$ in the regression of $\Delta_{y t} . \tilde{\psi}_{x}$, is found with $y_{1}-Z_{1} \delta$ where $y_{1}$ and $Z_{1}$ are the first elements of $y_{t}$ and $Z_{t}$ in the order specified (Lee and Strazicich, 2003: 1083).

Critical values accepted for single and double fracture unit root tests are obtained from the studies for a single fracture in Lee and Strazicich (2004), two fractures in Lee and Strazicich (2003). If a test statistic greater than the critical values is obtained, the unit root basic hypothesis containing the structural break is rejected (Y1lanc1, 2009: 331).

\section{Toda-Yamamoto Causality Test Procedure}

This method, developed by Toda and Yamamoto (1995), was created to take the Granger causality test to a higher level. In addition, the model tries to enhance some of the problems that occur in the Granger causality test. To be able to test 
Granger causality for time series, the series must first become stationary and stabilize at the same level. However, once this condition has been met, cointegration must also occur to demonstrate a long-term relationship between stationary series at the same level. In other words, only the Granger causality test can be performed between the series that are stable at the same level and have a cointegration relationship between them.

However, the Toda-Yamamoto test reveals that time series which are at different levels of stability may have causality between them, and even causality testing can be done without the need for a stationary test. This model can also be tested regardless of whether there is a cointegration between the series, regardless of cointegration (Toda and Yamamoto, 1995).

Toda-Yamamoto (1995) first stage of the test; the lag length in the model (k) is determined by the VAR model. Then, in the second stage of the model, the variable with the highest degree of integration, the degree of integration $\left(d_{\max }\right)$ is added to the lag length $(\mathrm{k})$ of the model. In the third stage, the VAR model is estimated according to the lag with the level values $\left(\mathrm{k}+\left(d_{\max }\right)\right.$ of the series. In the final stage, constraints are added to the coefficients from $\left(d_{\max }\right)$ and the significance of the constraints added using the modified Wald statistic is tested. The VAR model developed by Toda-Yamamoto (1995) is applied with the help of the following equations (Şahin and Durmuş, 2018: 819);

$$
\begin{gathered}
Y_{t}=a_{0}+\sum_{i=1}^{k+d_{\max }} a_{1 i} Y_{t-i}+\sum_{i=1}^{k+d_{\max }} a_{2 i} X_{t-i}+u_{t} \\
X_{t}=\beta_{0}+\sum_{i=1}^{k+d_{\max }} \beta_{1 i}+\sum_{i=1}^{k+d_{\max }} \beta_{2 i} Y_{t-i}+v_{t}
\end{gathered}
$$

In the Toda-Yamamoto test, the basic hypothesis and alternative hypothesis can be discussed as follows.

$\mathrm{H}_{0}$ : The $\mathrm{X}$ variable is not the Granger cause of the $\mathrm{Y}$ variable.

$\mathrm{H}_{1}$ : The $\mathrm{X}$ variable is the Granger cause of the $\mathrm{Y}$ variable.

The success of the Toda-Yamamoto causality test is directly related to the correct determination of the value of the series $\left(d_{\max }\right)$ and $(k)$ in the model (Çil Yavuz, 2006: 169). 


\section{EMPIRICAL RESULTS}

In this study, it is aimed to test the existence of a relationship between COVID-19, Bitcoin and 4 precious metals. Accordingly, the Toda-Yamamoto causality test is used in the study conducted using daily data between 19.01.2020 and 31.03.2021. Firstly, unit root tests are performed using Lee-Strazicich (LM) unit root test in order to ensure the stationary of the data obtained. LM test has advantages in terms of showing breaks on the data and it is shared with the break dates in this study. After obtaining the stationary data, causality test is carried out by using Toda-Yamamoto test. The analysis is carried out in the form of a double test. In the equation, the number of COVID-19 cases and COVID-19 google trends are taken as independent variables while Bitcoin, Gold, Silver, Platinum and Palladium are taken as dependent variables.

\section{The Results of Lee-Strazicich Unit Root Test}

In this study, the $\mathrm{C}$ model is chosen as the appropriate model to determine the breaks in the Lee-Strazicich Unit Root Test (LS). LS tests are applied again by taking the differences of the series that are not stationary in the level values. Findings obtained are shown in Table 2.

Table 2. The Results of Lee-Strazicich Unit Root Test

\begin{tabular}{|c|c|c|c|c|c|c|}
\hline \multicolumn{7}{|c|}{ Lee-Strazicich Unit Root Test (Model C) } \\
\hline \multirow{2}{*}{ Variable } & Level & \multirow{2}{*}{$\begin{array}{l}\text { Level } \\
\text { Breaking } \\
\text { Date }\end{array}$} & \multirow{2}{*}{$\begin{array}{l}\text { Critic } \\
\text { Value }\end{array}$} & \multirow{2}{*}{$\begin{array}{c}1 . \\
\text { Difference } \\
\text { Test } \\
\text { Statistics } \\
\end{array}$} & \multirow{2}{*}{$\begin{array}{c}1 . \\
\text { Difference } \\
\text { Breaking } \\
\text { Date } \\
\end{array}$} & \multirow{2}{*}{$\begin{array}{l}\text { Critic } \\
\text { Value }\end{array}$} \\
\hline & $\begin{array}{c}\text { Test } \\
\text { Statistics } \\
\end{array}$ & & & & & \\
\hline COVID & $\begin{array}{c}- \\
5.189260 * \\
\end{array}$ & 26.03.2020 & $\begin{array}{c}- \\
3.957884 \\
\end{array}$ & - & - & - \\
\hline TRENDS & $\begin{array}{c}- \\
5.295729 * \\
\end{array}$ & 16.03.2020 & $\begin{array}{c}- \\
3.961099 \\
\end{array}$ & - & - & - \\
\hline BTC & -3.776763 & 03.11 .2020 & $\begin{array}{c}- \\
4.068955 \\
\end{array}$ & $-12.17216^{*}$ & 13.10 .2020 & $\begin{array}{c}- \\
4.079602 \\
\end{array}$ \\
\hline GOLD & $\begin{array}{c}- \\
4.546688 *\end{array}$ & 23.07.2020 & $\begin{array}{c}- \\
4.079450 \\
\end{array}$ & - & - & - \\
\hline SLVR & -3.499070 & 21.07.2020 & $\begin{array}{c}- \\
4.077853 \\
\end{array}$ & $-10.56343 *$ & 25.09.2020 & $\begin{array}{c}- \\
4.091940 \\
\end{array}$ \\
\hline PLAT & -3.930868 & 27.04 .2020 & $\begin{array}{c}- \\
3.962583 \\
\end{array}$ & $-8.616760 *$ & 12.02.2021 & $\begin{array}{c}- \\
3.959707 \\
\end{array}$ \\
\hline PALD & $\begin{array}{c}- \\
5.478368 *\end{array}$ & 10.03.2020 & 3.959565 & - & - & - \\
\hline
\end{tabular}

*: It is significant at $5 \%$ level 


\section{$\underline{\text { A.Serbetci-Y.Alptürk-T.Ceyhan } \quad \text { Koronavirüs Salgını ve Bilinirliğgi... }}$}

According to the LS unit root test results; if the test statistic is greater than the critical value as the absolute value, the series is decided to be stationary. According to this evaluation, it is observed that COVID, TRENDS, GOLD, PALD data are stable at the level, and BTC, SLVR, PLAT variables are not stationary in level values and become stationary after taking the first differences.

\section{The Results of the Toda-Yamamoto Causality Test}

Toda-Yamamoto model is used to examine the causality between the series. Tests are carried out as a double test. While performing the Toda-Yamamoto test, the lag length $(k)$ of the series is found in regard to the Akaike Information Criterion (AIC), and the maximum degree of integration $\left(d_{\max }\right)$ in regard to the Lee-Strazicich unit root test. Then, it is tried to determine whether there is a causality relationship by applying Wald statistics to lagged values (k) in this model.

Tablo 3. The Results of the Toda-Yamamoto Causality Test

\begin{tabular}{|c|c|c|c|c|c|c|}
\hline $\begin{array}{c}\text { Dependent } \\
\text { Variables } \\
\text { (Y) }\end{array}$ & $\begin{array}{l}\text { Independent } \\
\text { Variable } \\
\text { (X) }\end{array}$ & $d_{\text {max }}$ & $\mathbf{K}$ & $\begin{array}{c}\text { Chi-Square Test } \\
\text { Statistics }\end{array}$ & $\begin{array}{c}\text { Chi- } \\
\text { Square } \\
\text { Test } \\
\text { Value } \\
\end{array}$ & Relation \\
\hline TRENDS & \multirow{6}{*}{ COVID } & 1 & 10 & 66.19009 & $0.0000^{*}$ & Acceptance \\
\hline BTC & & 1 & 10 & 3.802745 & 0.9558 & Rejection \\
\hline GOLD & & 1 & 10 & 4.335726 & 0.9309 & Rejection \\
\hline SLVR & & 1 & 10 & 4.550861 & 0.9191 & Rejection \\
\hline PLAT & & 1 & 10 & 4.403441 & 0.9273 & Rejection \\
\hline PALD & & 1 & 10 & 8.496468 & 0.5805 & Rejection \\
\hline
\end{tabular}

*It is significant at $5 \%$ level. The optimal lag length is determined according to the (AIC) criteria. In addition, the table shows the maximum stagnation level by taking the shared dmax $=$ Lee Strazicich unit root test. $(\mathrm{k})$ shows the VAR lag length.

$H_{0}$ : The independent variable is not the Granger cause of the dependent variable.

$H_{1}$ : The independent variable is the Granger cause of the dependent variable.

According to the findings in Table 3, there is a causality from the confirmed number of COVID-19 cases to the COVID-19 google trends data. Since the ChiSquare test value of the analysis is less than 0.05 , it is seen that the $H_{0}$ (basic) hypothesis established at the $5 \%$ significance level is rejected while the alternative hypothesis $H_{1}$ is not rejected. On the other hand, the basic hypothesis established at the 5\% significance level towards the BTC, GOLD, SLVR, PLAT, PALD series from the COVID series is not rejected. In other words, a causality relationship has not been found from the number of COVID-19 cases to Bitcoin and precious metals. 
Tablo 4. The Results of the Toda-Yamamoto Causality Test

\begin{tabular}{|c|c|c|c|c|c|c|}
\hline $\begin{array}{c}\text { Dependent } \\
\text { Variables } \\
(Y) \\
\end{array}$ & $\begin{array}{c}\text { Independent } \\
\text { Variable } \\
\text { (X) } \\
\end{array}$ & $d_{\max }$ & $\mathbf{K}$ & $\begin{array}{c}\text { Chi-Square } \\
\text { Test Statistics }\end{array}$ & $\begin{array}{l}\text { Chi-Square } \\
\text { Test Value }\end{array}$ & Relation \\
\hline COVID & \multirow{6}{*}{ TRENDS } & 1 & 10 & 28.56567 & $0.0015 *$ & Acceptance \\
\hline BTC & & 1 & 9 & 88.97787 & $0.0000^{*}$ & Acceptance \\
\hline GOLD & & 1 & 10 & 26.59552 & $0.0030 *$ & Acceptance \\
\hline SLVR & & 1 & 3 & 4.433652 & 0.2183 & Rejection \\
\hline PLAT & & 1 & 9 & 37.06489 & $0.0000 *$ & Acceptance \\
\hline PALD & & 1 & 11 & 42.51537 & $0.0000 *$ & Acceptance \\
\hline
\end{tabular}

*It is significant at $5 \%$ level. The optimal lag length is determined according to the (AIC) criteria. In addition, the table shows the maximum stagnation level by taking the shared dmax $=$ Lee Strazicich unit root test. $(\mathrm{k})$ shows the VAR lag length.

$H_{0}$ : The independent variable is not the Granger cause of the dependent variable.

$H_{1}$ : The independent variable is the Granger cause of the dependent variable.

According to the findings presented in Table 4, the basic hypothesis $\left(H_{0}\right)$ established at the 5\% significance level from the TRENDS variable to the variables COVID, BTC, GOLD, PLAT, PALD is rejected. On the other hand, the basic hypothesis established at the 5\% significance level from the TRENDS series to the SLVR series is not rejected. More clearly, a causality relationship is found from COVID-19 recognition to confirmed case numbers, Bitcoin and Gold, Platinum and Palladium while no causality relationship is found from COVID19 recognition to silver prices.

\section{CONCLUSION}

In this study, we have tried to find some evidence that virus has effects in global markets. Based on this, Google search trend data were used for medical data and coronavirus recognition. Here, the effects of the number of cases caused by the virus and the panic caused by the recognition of the virus on financial instruments seen as safe port were examined.

For this purpose, the Lee-Strazicich unit root test was used to test the stationarity of the series using daily data between 19.01.2020 and 31.03.2021. While some variables were stationary in level values, the series that were not stable, were made stationary by taking the first differences. Then, the optimal lag length was determined to be used in causality analysis. Whether there was any causality among the variables was investigated by the Toda-Yamamoto causality test. In the study, analyses were made in the form of double tests. In addition, the 


\section{$\underline{\text { A.Serbetci-Y.Alptürk-T.Ceyhan } \quad \text { Koronavirüs Salgını ve Bilinirliğgi... }}$}

number of cases and Google COVID-19 search data as COVID-19 indicators were taken as independent variables.

According to the results of the Lee-Strazicich unit root test, it was observed that the number of COVID-19 cases, COVID-19 google trends, gold and palladium were stationary at the level, and the variables of bitcoin, silver and platinum became stationary after the first differences are taken. According to the results of the Toda-Yamamoto causality test, no causality relationship was found between the number of COVID-19 cases and the closing prices of Bitcoin and precious metals while a mutual causality relationship was found between the number of COVID-19 cases and the recognition of COVID-19. Besides, no causality relationship was found from the recognition of COVID-19 to silver closing prices while there was a causality from the recognition of COVID-19 to gold, platinum, palladium and Bitcoin closing prices.

While the increase in the recognition of COVID-19 has affected the Bitcoin and precious metal prices, no effect of the number of COVID-19 cases on Bitcoin and precious metals was detected. Besides, mutual effects were identified between the number of COVID-19 cases and the recognition of COVID-19. In the study in which coronavirus was evaluated as the dependent variable, the recognition of coronavirus has causality relationships at 5\% significance level on all variables except silver.

According to the results of the study, the increasing popularity of COVID-19 has a strong effect on the prices of Bitcoin and gold, platinum and palladium depending on the variables selected and time period. It can be said that the demand for precious metals, which are relatively low-risk and seen as safe haven by investors who don't want to take risks, is increasing in the coronavirus process. Moreover, it can be argued that investors looking for different investment alternatives during the epidemic period turned to Bitcoin. On the other hand, the reason why there is no relationship with silver may be the traditional approaches of investors on silver. Although gold and silver are accepted as saving commodity in the markets; when these two precious metals are compared, gold is accepted as an investment tool while silver is considered as industrial. For this reason, it is thought that investors do not consider silver as a port and they abstain from taking shelter in it during the period when the risks due to the coronavirus increase.

Therefore, this study is a guide for international investors in terms of its empirical findings. In addition, it is thought that it will save time and effort for policy makers and academic studies in this field, and it is hoped that it will lead to studies in this field in terms of timing. 


\section{REFERENCES}

Açacak, A., Gülsar, E., and Meriç, E. (2020). Kıymetli madenlerin birbirleriyle ilişkisi: asimetrik nedensellik, Anadolu Üniversitesi Íktisadi ve İdari Bilimler Fakültesi Dergisi, 21(1), 28-37.

Aksoy, M. and Topçu, N. (2013). Altın ile hisse senedi ve enflasyon arasındaki ilişki, Atatürk Üniversitesi İIBF Dergisi, 27(1), 59-78.

Armien, B., Suaya, J.A., Quiroz, E., Sah, B.K., Bayard, V., Marchena, L., Campos, C. and Shepard, D.S. (2008). Clinical characteristics and national economic cost of the 2005 Dengue Epidemic in Panama, The American Journal of Tropical Medicine and Hygiene, 79(3), 364-371.

Arouri, M.E.H., Hammoudeh, S., Lahiani, A., and Nguyen, D.K. (2012). Long memory and structural breaks in modeling the return and volatility dynamics of precious metals, The Quarterly Review of Economics and Finance, 52(2), 207-218.

Avşarlıgil, N. (2020). Covid-19 salgının Bitcoin ve diğer finansal piyasalar ile ilişkisi üzerine bir inceleme, Alanya Akademik Bakış Dergisi, 4(3), 665682.

Balc1lar, M., Bouri, E., Gupta, R. and Roubaud, D. (2017). Can volume predict Bitcoin returns and volatility? A quantiles-based approach, Economic Modelling, 64, 74-81.

Batten, J.A., Ciner, C. and Lucey, B.M. (2010). The macroeconomic determinants of volatility in precious metals markets, Resources Policy, 35(2), 65-71.

Bhatia, V., Das, D., Tiwari, A.K., Shahbaz, M. and Hasim, H.M. (2018). Do precious metal spot prices influence each other? Evidence from a nonparametric causality-in-quantiles approach, Resources Policy, (55), 244-252.

Blau, B.M. (2017). Price dynamics and speculative trading in Bitcoin, Research in International Business and Finance, 41, 493-499.

Bobdey S. and Ray, S. (2020). Going viral-covid-19 impact assessment: a perspective beyond clinical practice, Journal of Marine Medical Society, 22(1), 9-12. 
Bouri, E., Azzi, G. and Dyhrberg, A.H. (2017a). On the return-volatility relationship in the Bitcoin market around the price crash of 2013, Economics: The Open-Access, Open-Assessment E-Journal, 11(2), 1-16. doi:10.2139/ssrn.2869855.

Bouri, E., Gupta, R., Tiwari, A.K. and Roubaud, D. (2017b). Does Bitcoin hedge global uncertainty? Evidence from wavelet-based quantile-in-quantile regressions, Finance Research Letters, 23, 87-95.

Bouri, E., Jalkh, N., Molnár, P. and Roubaud, D. (2017c). Bitcoin for energy commodities before and after the december 2013 crash: diversifier, hedge or safe haven, Applied Economics, 49(50), 5063-5073.

Bouri, E., Molnár, P., Azzi, G., Roubaud, D. and Hagfors, L. I. (2017d). On the hedge and safe haven properties of Bitcoin: is it really more than a diversifier? Finance Research Letters, 20, 192-198.

Bouri, E., Gupta, R., Lahiani, A. and Shahbaz, M. (2018). Testing for asymmetric nonlinear short-and long-run relationships between Bitcoin, aggregate commodity and gold prices, Resources Policy, 57, 224-235.

Cermak, V. (2017). Can Bitcoin become a viable alternative to fiat currencies? An empirical analysis of bitcoin's volatility based on a GARCH model, SSRN Electronic Journal, doi:10.2139/ssrn.2961405.

Chen, M.-H., Jang, S.S. and Kim, W.G. (2007). The impact of the SARS outbreak on Taiwanese hotel stock performance: an event-study approach, International Journal of Hospitality Management, 26(1), 200-212.

Çelik, İ., Akkuş, H.T. and Gülcan, N. (2019), Emtia piyasalarında rasyonel balonlar ve volatilite yayılımlarının araştırılması: değerli metallerden kanitlar, Mehmet Akif Ersoy Üniversitesi İktisadi ve İdari Bilimler Fakültesi Dergisi, 6(3), 936-951.

Çil Yavuz, N. (2006). Türkiye'de turizm gelirlerinin ekonomik büyümeye etkisinin testi: yapısal kırılma ve nedensellik analizi, Doğuş Üniversitesi Dergisi, 7(2), 162-171.

Dyhrberg, A.H. (2016). Bitcoin, gold and the dollar- A GARCH volatility analysis, Finance Research Letters, (16), 85-92.

Giudice, A.D. and Paltrinieri, A. (2017). The impact of the Arab Spring and the Ebola outbreak on African equity mutual fund investor decisions, Research in International Business and Finance, 41, 600-612. 
Google Trends (2020). Coronavirus research dates, https://trends. google.com/ trends/?geo=TR, [Date of Access: 1 April 2021].

Gujarati, D. (2016), Örneklerle ekonometri (Çev. Nasip BOLATOĞLU), BB101 yayınları, ANKARA.

Gülcan, N. (2021). Değerli maden ve enerji ürünlerinin COVİD-19 küresel pandemiye tepkisi: Türkiye örneği, 291-312, COVID-19'un Muhasebe ve Finans Yansımaları içinde, 13. Bölüm, (Ed: Turan Öndeş, Ceyda Yerdelen Kaygin), Gazi Kitabevi, Ankara.

Investing.com (2020). Commodities and crypto, https://www.investing.com/, [Date of Access: 1 April 2021].

Iqbal, N., Fareed, Z., Wan, G. and Shahzad, F. (2021). Asymmetric bexus between Covid-19 outbreak in the world and cryptocurrency market, International Review of Financial Analysis, (73), 1-16.

Karataş, T. and Ürkmez, E. (2013). Küresel kriz sürecinde altın fiyatlarını etkileyen dinamikler, International Conference on Eurasian Economies 2013, Beykent Üniversitesi, September 17-18, 2013, St. PetersburgRussia, 558-564.

Lee, Chien-C. and Chang, Chun-P. (2008). Unemployment hysteresis in OECD countries: centurial time series evidence with structural breaks, Economic Modelling, 25(2), 312-325.

Lee, J. and Strazicich, M.C. (2003). Minimum lagrange multiplier unit root test with two structural breaks, Review of Economics and Statistics, 85(4), 1082-1089.

Lee, J. and Strazicich, M.C. (2004). Minimum LM unit root test with one structural break, Department of Economics Working Papers, No:04-17, Appalachian State University.

Loh, E. (2006). The impact of SARS on the performance and risk profile of airline stocks, International Journal of Transport Economics, 33(3), 401-422.

Lucey, B.M. and Li, S. (2015). What precious metals act as safe havens, and when? Some US evidence, Applied Economics Letters, 22(1), 35-45.

Ministry of Health (2020). COVID-19 (SARS-CoV-2 enfeksiyonu): genel bilgiler, epidemiyoloji ve tanı, Ankara: T.C. Să̆glk Bakanlı̆̆ Halk Sağllğgl Genel Müdürlü̆̈̈̈, https://covid19.saglik.gov.tr/Eklenti/39551/0/ covid- 
19rehberigenelbilgile repidemiyoloji vetanipdf.pdf, [Date of Access: 1 January 2021].

Özcan, B. (2012). İşsizlik histerisi hipotezi OECD ülkeleri için geçerli mi? Yapısal kırılmalı birim kök analizi, Erciyes Üniversitesi Iktisadi ve Idari Bilimler Fakültesi Dergisi, (40), 95-117.

Öztürk, Ö., Şişman, M.Y., Uslu, H. and Çıtak, F. (2020). Effects of COVID-19 outbreak on Turkish stock market: a sectoral-level analysis, Hitit Üniversitesi Sosyal Bilimler Enstitüsü Dergisi, 13(1), 56-68.

Peng, Y., Albuquerque, P.H.M., Camboim de S.J.M., Padula, A.J.A. and Montenegro, M.R. (2018). The best of two worlds: forecasting high frequency volatility for cryptocurrencies and traditional currencies with support vector regression, Expert Systems with Applications, 97, 177192.

Reboredo, J.C. (2013). Is gold a hedge or safe haven against oil price movements? Resources Policy, 38(2), 130-137.

Şahin, D. and Durmuş, S. (2018). Türkiye'de ekonomik büyüme, ihracat ve hisse senedi fiyatları arasındaki nedensellik ilişkisinin analizi, Avrasya Uluslararası Araştırmalar Dergisi, 6(15), 808-825.

Temür, A. (2021). Koronavirüs COVID-19'un dünya borsaları üzerine etkisi ve BİST-perakende sektöründeki hisse senetlerinin bu süreçteki davranışları, Finansal Araştırmalar ve Çalışmalar Dergisi, 13(25), 773797.

Tiwari, A.K., Jana, R.K., Das, D. and Roubaud, D. (2018). Informational efficiency of bitcoin-an extension, Economics Letters, 163, 106-109.

Toda, H.Y. and Yamamoto, T. (1995). Statistical inference in vector autoregressions with possibly integrated processes, Journal of Econometrics, 66(1-2), 225-250.

WHO (2020). Q\&A on coronaviruses (COVID-19), https://www.who.int/news room/q-a-detail/q-a-coronaviruses, [Date of Access: 1 January 2021].

Yılancı, V. (2009). Yapısal kırılmalar altında Türkiye için işsizlik histerisinin sınanması, Doğuş Üniversitesi Dergisi, 10(2), 324-335.

Yıldırım, H. (2018). Günlük Bitcoin ile altın fiyatları arasındaki ilişkinin test edilmesi: 2012-2013 yılları arası Johansen eşbütünleşme testi, İnsan ve Toplum Bilimleri Araştırmaları Dergisi, 7(4), 2328-2343. 
Zeren, F. and Hizarc1, A.E. (2020). The impact of Covid-19 coronavirus on stock markets: evidence from selected countries, Muhasebe ve Finans Incelemeleri Dergisi, 3(1), 78- 84. 